Supplement of Atmos. Chem. Phys., 17, 8231-8246, 2017

https://doi.org/10.5194/acp-17-8231-2017-supplement

(C) Author(s) 2017. This work is distributed under

the Creative Commons Attribution 3.0 License.

(c) (1)

Supplement of

\title{
Long-term change in the source contribution to surface ozone over Japan
}

Tatsuya Nagashima et al.

Correspondence to: Tatsuya Nagashima (nagashima.tatsuya@ nies.go.jp)

The copyright of individual parts of the supplement might differ from the CC BY 3.0 License. 


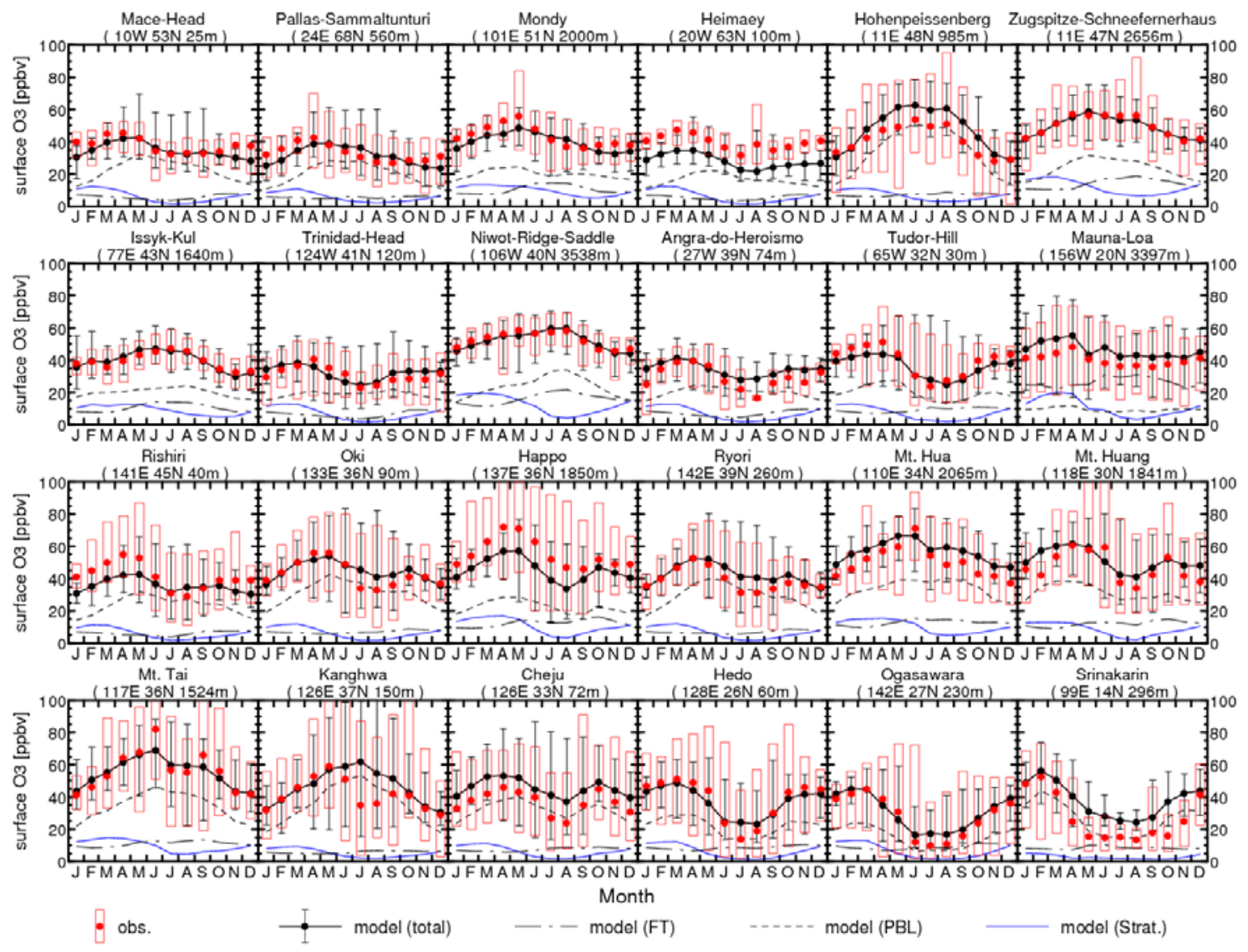

Figure S1. Seasonal variations of the monthly mean surface $\mathrm{O}_{3}$ observations (red filled circles) and model calculations (black circles and thick black solid lines), with contributions from the stratosphere (blue solid lines), PBL (black dashed lines), and FT (black dash-dotted lines) estimated by the model. Monthly means and each contribution are multiyear (six years for the model and available years for the observations) averaged values for 2000-2005. Vertical bars and boxes denote the multiyear range of the daily mean surface $\mathrm{O}_{3}$ for each month for the model and the observations, respectively. 
Table S1. Statistical summary of the comparison between the observed (Obs) and modeled (Model) surface $\mathrm{O}_{3}$ at observational sites shown in Figure $\mathrm{S} 1$. $\mathrm{R}$ is correlation coefficients, MB is mean bias, and RMSE is root mean square error.

\begin{tabular}{|c|c|c|c|c|c|}
\hline Station name & $\begin{array}{r}\text { Mean (Obs) } \\
{[\mathrm{ppbv}]}\end{array}$ & $\begin{array}{l}\text { Mean (Model) } \\
{[\text { [ppbv] }}\end{array}$ & $\mathrm{R}$ & $\begin{array}{r}\text { MB } \\
\text { [ppbv] }\end{array}$ & $\begin{array}{l}\text { RMSE } \\
\text { [ppbv] }\end{array}$ \\
\hline Mace-Head & 37.81 & 34.5 & 0.63 & -3.31 & 5.08 \\
\hline Pallas-Sammaltunturi & 33.02 & 31.38 & 0.6 & -1.64 & 4.95 \\
\hline Mondy & 43.5 & 40.08 & 0.8 & -3.42 & 5.13 \\
\hline Heimaey & 39.75 & 28.12 & 0.87 & -11.63 & 11.83 \\
\hline Hohenpeissenberg & 41.05 & 47.48 & 0.94 & 6.43 & 8.27 \\
\hline Zugspitze-Schneefernerhaus & 49.81 & 49.33 & 0.97 & -0.48 & 1.5 \\
\hline Issyk-Kul & 39.54 & 39.65 & 0.93 & 0.11 & 2.12 \\
\hline Trinidad-Head & 30.92 & 32.09 & 0.67 & 1.17 & 3.95 \\
\hline Niwot-Ridge-Saddle & 52.76 & 52.03 & 0.92 & -0.73 & 2.29 \\
\hline Angra-do-Heroismo & 29.49 & 34.26 & 0.88 & 4.77 & 6.05 \\
\hline Tudor-Hill & 39.54 & 35.95 & 0.96 & -3.59 & 4.74 \\
\hline Mauna-Loa & 40.15 & 46.26 & 0.86 & 6.11 & 6.57 \\
\hline Rishiri & 41.33 & 35.52 & 0.76 & -5.81 & 7.97 \\
\hline Oki & 43 & 44.51 & 0.8 & 1.51 & 4.94 \\
\hline Нарро & 55.58 & 45.43 & 0.92 & -10.15 & 10.78 \\
\hline Ryori & 39.06 & 42.45 & 0.83 & 3.39 & 5.03 \\
\hline Mt. Hua & 50.29 & 56.69 & 0.92 & 6.4 & 7.59 \\
\hline Mt. Huang & 47.23 & 51.47 & 0.77 & 4.24 & 7.1 \\
\hline Mt. Tai & 56.18 & 55.16 & 0.93 & -1.02 & 5.13 \\
\hline Kanghwa & 41.33 & 46.29 & 0.58 & 4.96 & 10.24 \\
\hline Cheju & 36.75 & 45.46 & 0.92 & 8.71 & 9.15 \\
\hline Hedo & 38.42 & 37.01 & 0.96 & -1.41 & 4.76 \\
\hline Ogasawara & 28.08 & 30.28 & 0.96 & 2.2 & 4.15 \\
\hline Srinakarin & 27.35 & 38 & 0.92 & 10.66 & 12.26 \\
\hline
\end{tabular}




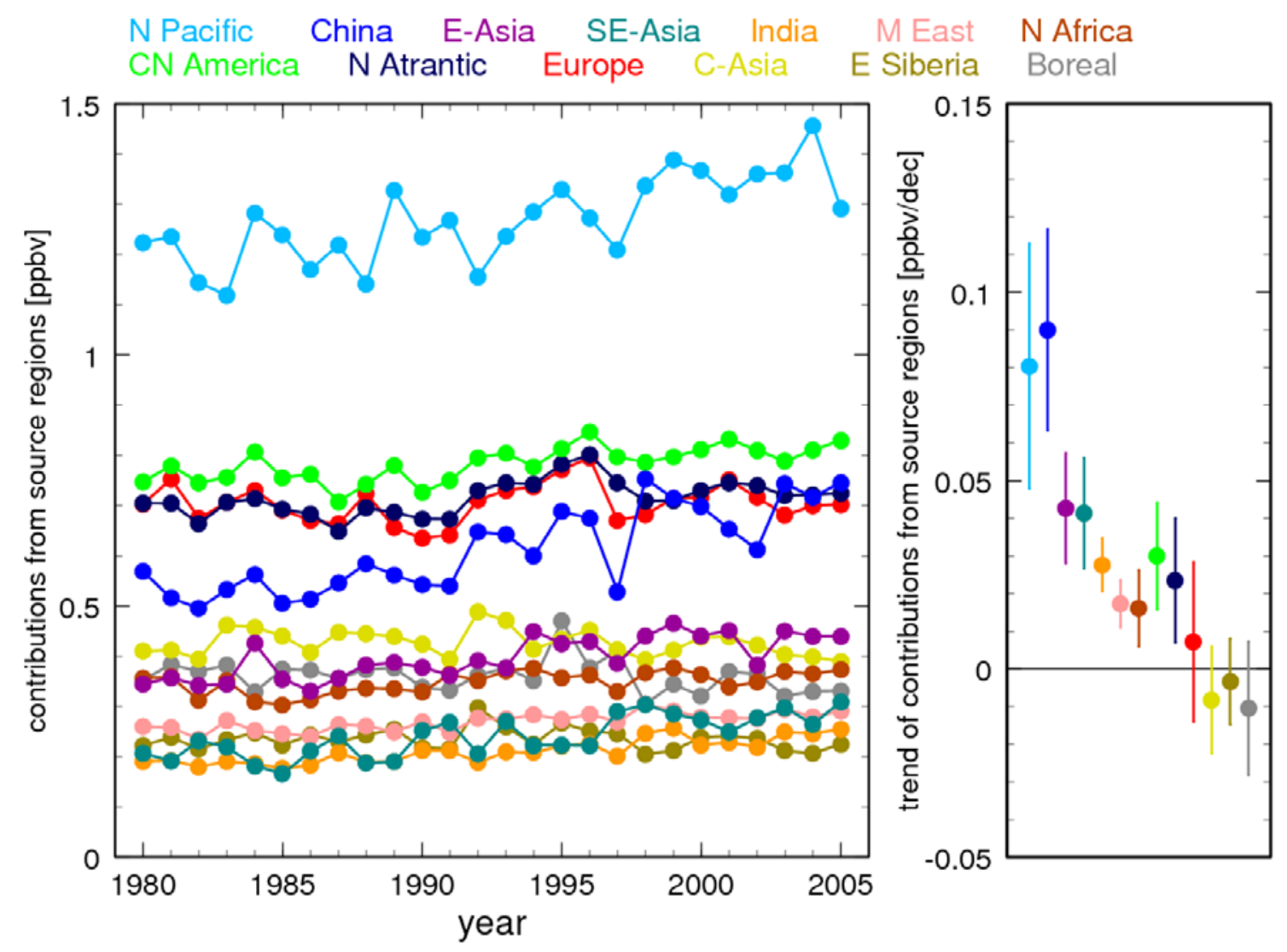

Figure S2. (Left) The long-term changes of annual mean contributions from source regions in the free troposphere in the Northern Hemisphere to surface $\mathrm{O}_{3}$ over Japan. Some source regions are grouped: E-Asia is the sum of JPN, KOR, JPS, and ECS; SE-Asia is the sum of IDN and IDC; and CN America is the sum of AMC and AMN. (Right) The linear trends of the regional contributions in the left panel are for 1980-2005. Error bars are the $95 \%$ confidence intervals. 